DE9 1005833

\title{
APPLICATION OF THE MONOLITHIC SOLID-OXIDE FUEL CELL TO SPACE POWER SYSTEMS
}

\author{
Kevin M. Myles \\ Electrochemical Technology Progran \\ Argonne National Laboratory \\ 9700 South Cass Avenue \\ Argonne, nllinois 60439 \\ (708) $972-4329$
}

\author{
Samit K. Bhattacharyya \\ Engineering Research Division \\ Argonne National Laboratory \\ 9700 South Cass Avenue \\ Argonne, Illinois 60439 \\ (708) $972-3293$
}

CAMERA READY MANUSCRIPT prepared for:

Eighth Symposium

on Space Nuclear Power Systems

Albuquerque, New Mexico

6-10 January 1991

initial submission:

Author to whom correspondence should be sent:

Dr. Kevin M. Myles

\section{DISCLAIMER}

This report was prepared as an account of work sponsored by an agency of the United Siates Government. Neither the United States Government nor any agency thereof, nor any of their employees, makes any warranty, express or implied, or assumes any legal liability or responsiemployees, makes any warranty, express or implied, or assumes any information, apparatus, product, or process disclosed, or represents that its use would not infringe privaiely owned rights. Reference herein to any specific commercial product, process, or service by trade name, trademark, manufacturer, or otherwise does not necessarily constitute or imply its endorsement, recommendation, or favoring by the United States Government or any agency thereof. The views and opinions of cuthors expressed herein do not necessarily state or reflect those of the United States Government or any agency thereof.

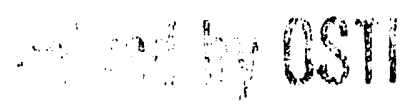




\title{
APPLICATION OF THE MONOLITHIC SOLID-OXIDE FUEL CELL TO SPACE POWER SYSTEMS
}

\author{
Kevin M. Myles \\ Electrochemical Technology Program \\ Argonne National Laboratory \\ 9700 South Cass Avenue \\ Argonne, IL 60439
}

(708) $972-4329$

\author{
Samit K. Bhattacharyya \\ Engineering Rescarch Division \\ Argonne National Laboratory \\ 9700 South Cass Avenue \\ Argonne, IL 60439 \\ (708) $972-3293$
}

\begin{abstract}
$\underline{\text { Abstract }}$
The current status of the fabrication and perfnrmatue of the promising monolithic solid oxide fuel cell are presented. The fuel cell to space power systems is discussed.

\section{INTRODUCTION}

The monolithic solid-oxide fuel cell (MSOFC) has been under development at Argonne National Laboratory since 1983. The unique design of the MSOFC provides the promise of exceptionally high power and energy densities that can be particularly beneficial to space power systems. The MSOFC is an oxide ceramic structure in which appropriate electronic and ionic conductors are fabricated in a "honeycomb" shape similar to a block of corrugated paperboard. The electrolyte that conducts oxygen ions from the air side to the fuel side is yttria-stabilized zirconia (YSZ). All the other materials are electronic conductors, including the nickel-YSZ anode, the strontium-doped lanthanum manganite cathode, and the doped lanthanum chromite interconnect (bipolar plate). These electronic and ionic conductors are arranged to provide short conduction paths to minimize resistive losses. The power density achievable with the MSOFC is expected to be about $8 \mathrm{~kW} / \mathrm{kg}$ or $4 \mathrm{~kW} / \mathrm{L}$ at fuel efficiencies over $50 \%$, because of small cell size and low resistive losses in the materials. These performances have been approached in laboratory test fuel cell stacks of nominal $125 \mathrm{~W}$ capacities. The MSOFC operates in the range $973 \mathrm{~K}$ to $1273 \mathrm{~K}$, at which temperatures rapid reform of hydrocarbon fuels is expected within the nickel-YSZ fuel channels.
\end{abstract}

\section{FABRICATION}

The MSOFC was originally tape casted but currently is hot roll calendered. The tape casting process consists of spreading a ceramic slurry (slip) uniformly on a substrate, such as glass or polymer film, using a doctor blade. After the slip is dry, the ceramic layer is stripped off the substrate in the form of a flexible "tape". The hot roll calendering process is shown in Figure 1, consists of mixing ceramic powder with organic binder and plasticizer and rolling the warm mixture into a thin tape. The "green" tapes are cut to the desired dimensions, and the electrode tapes are corrugated to form the gas flow channels. The corrugations are formed by folding the tape onto a warm mold. After cooling, the tape retains the corrugated shape. The corrugated electrode tapes and the flat electrolyte and interconnect tapes are stacked up in sequence to form the MSOFC structure. The layers are bonded together in the green state by heating the polymer binder slightly above its glass transition temperature under a small weight. The bonded green structure is then heated, according to a precise firing schedule, to the sintering temperature to form the monolithic ceramic structure. 


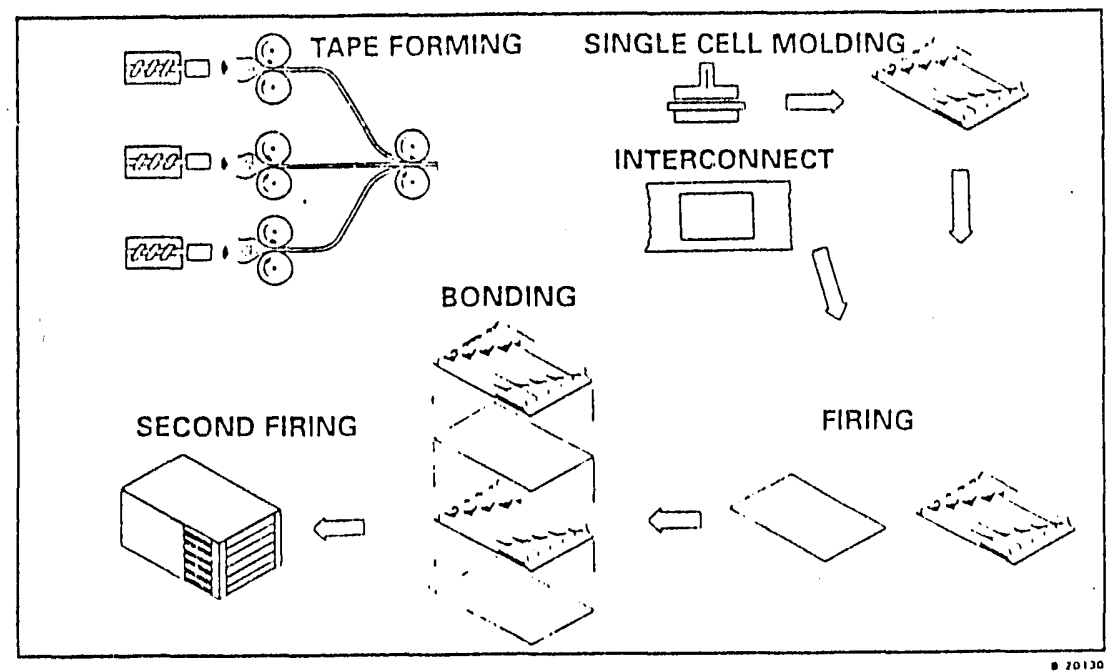

FIGURE 1. Hot Roll Calendering.

An advantage of the two-step cofiring hot roll calendering process is that the interconnect can be processed separately from the other layers. This allows higher sintering temperatures, eliminates shrinkage mismatches, and stops liquid-phase wicking, which hinders interconnect densification. Whereas the interconnect sheets and the cathode/electrolyte intermediate sheets have a high processing yield. The anode sheets have roughly a 60 percent processing yield which could be caused by variations in the thermal expansion within the anode layer that are the result of a nonuniform distribution of nickel.

In view of the brittle nature of ceramics, microstructural cracks are inherent and unavoidable in the ceramic components of MSOFC's. The presence of large failure-causing microstructural cracks in the MSOFC structure is a potential problem because of the possibility of these cracks propagating through the electrolyte and interconnect layers. Growth of these microstructural cracks as a result of fuel cell operation and thermal cycling, could result in leakage between the fuel and air passages. Therefore, to maintain the structural integrity of the MSOFC, the approach taken at ANL has been to increase the resistance to crack propagation and minimize the subcritical growth of inherent cracks by developing microstructures with improved fracture toughness. Fracture toughness can be improved by several techniques, including addition of second-phase particles. The second-phase particles may act as crackarresting sites, and thus increase fracture toughness. The second-phase particles could also induce microcracking in the matrix phase if there is a critical strain mismatch between the matrix and the second phase. The microcracks with appropriate size and density may absorb strain energy and improve fracture toughness. In the past, ANL has successfully used both crack pinning and microcracking techniques to fabricate tape-case $\mathrm{ZrO}_{2}$-based composite electrolytes with much improved fracture toughness. The feasibility of applying these techniques to calendered materials is being evaluated. Analytical anilysis of the stress patterns in the MSOFC are being made to predict the stresses incurred during fabrication and operation of the stock. Comparative analysis using an elastic mold and the ANYSY stress model have yielded essentially identically results.

To date, many three cell stacks and several light to ten cell stacks have been fabricated with the tape cast components. Two cell stacks and 50-W and 100-W (projected power) stacks have been fabricated with the two-step cofiring hot roll calendering process. A photograph of the $50-\mathrm{W}$ rated cross flow design stack is shown in Figure 2. A design of a 100-W stack that includes the fuel and oxidant manifolds is shown in Figure 3. 


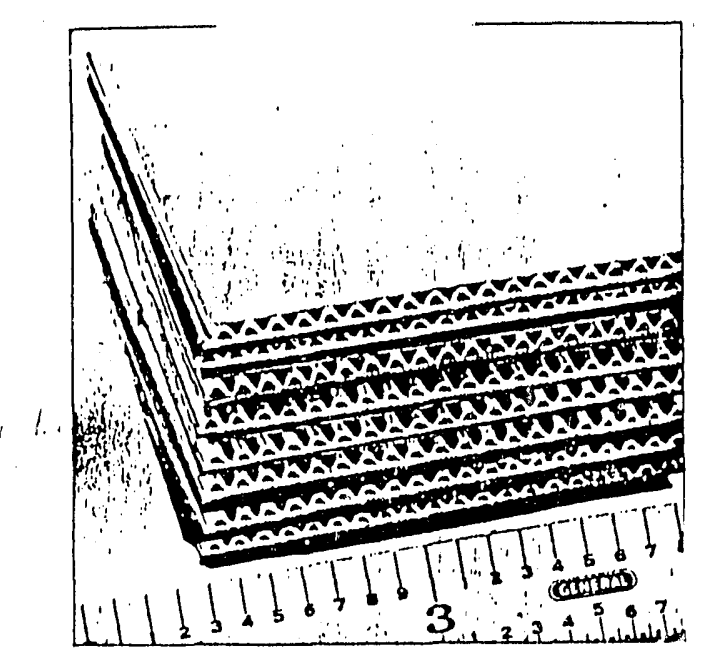

FIGURE 2. Crossflow MSOFC Stack as Fabricated.
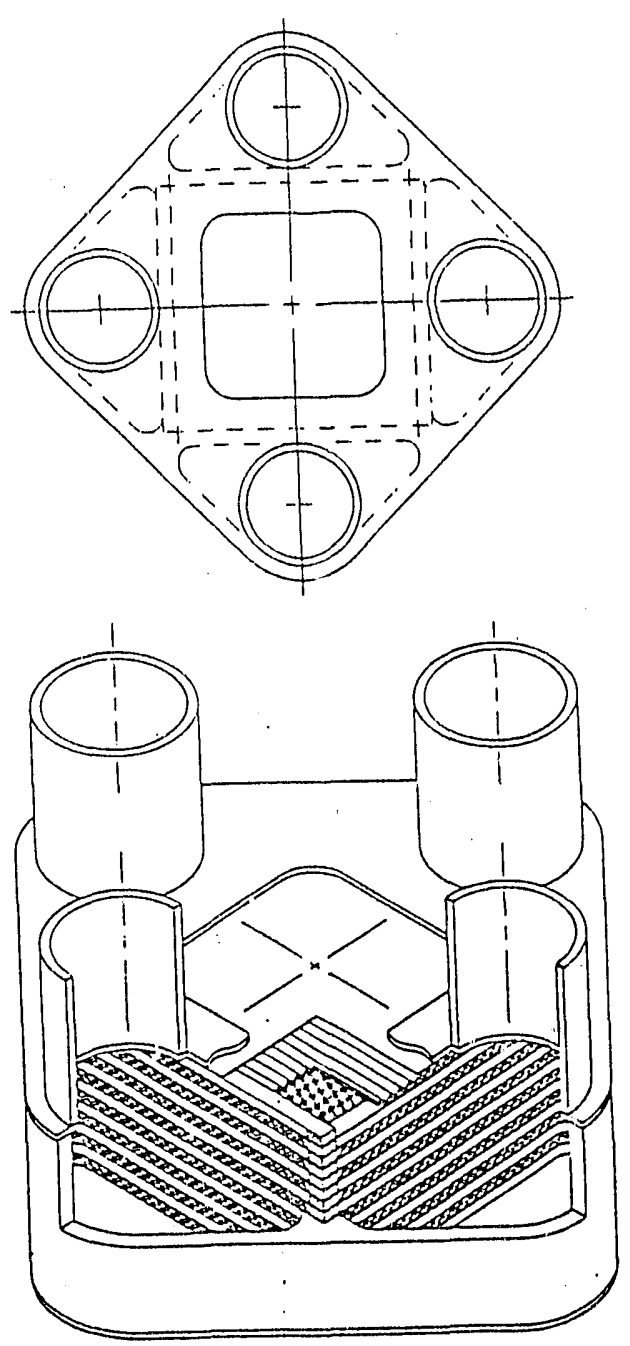

FIGURE 3. Cutaway Yiew of 100 Watt MSOFC Stack with Manifold Concept. 


\section{PERFORMANCE}

The performance of the MSOFC has improved significanuly during the course of development. Tests have been performed with both hydrogen and simulated coal gas as the fuel and with both pure oxygen and air as the oxidant. The results, as shown in Figure 4, show that the fuel geometry tested oxygen roughly doubles the achievable current density and hence power. 'The limitation of this system, based on materials resistance alone without interfacial resistances, is $0.05 \mathrm{ohm} \mathrm{cm}^{2}$. With further development, the area specific resistance is expected to be reduced below $0.1 \mathrm{ohm} \mathrm{cm}^{2}$, which will result in power levels greater than $2.5 \mathrm{~W} / \mathrm{cm}^{2}$. Extrapolations to large power systems can lead to the development of compact energy :torage devices that can play a significant role in the evolving Space Exploration Initiative.

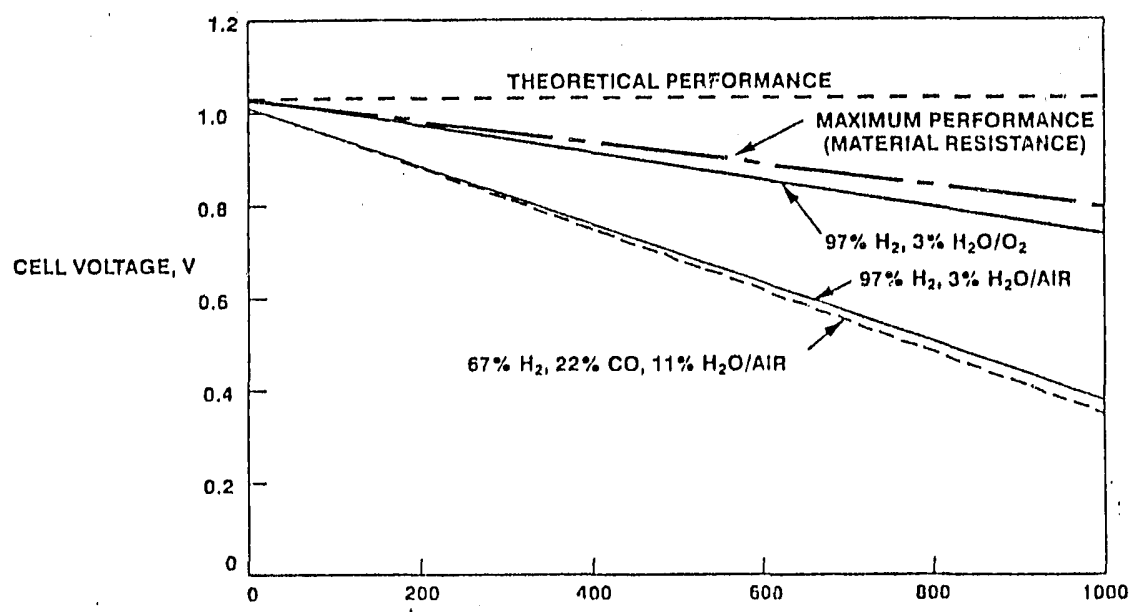

FIGURE 4. Cell Performance.

\section{SPACE POWER SYSTEMS}

Because of the high temperature of operation of the MSOFC and the compact fuel cell design, systems that incorporate the MSOFC for power production are very simple. The high temperature, combined with the use of nickel in the fuel electrode, allows internal reform of hydrocarbon fuels within the fuel channels, obviating the need for a separate fuel reformer. In addition, existing fuel logistics systems can be used with the MSOFC with essentially no modifications. Space-based systems that are required to regenerate the hydrogen fuel from the reaction product, water, are simplified by the fact that the MSOFC can use the same unit for power production and fuel regeneration. The high operating temperature of the MSOFC allows the waste heat to be rejected at a high temperature, thus minimizing the size of the heat rejection system. The MSOFC systems are flexible in terms of their ability to operate as an open cycle, closed cycle, or a combination of open and closed cycles. In this paper, we will present an example of an application of the MSOFC, coupled with a fast-spectrum nuclear reactor and operating in a regenerative mode to produce burst mode power for various space missions. 
The basic concept consists of a Li-cooled fast spectrum reactor coupled to a potassium Rankine cycle to generate steady applications. The power system is coupled electrically and thermally to a MSOFC power system that is designed to provide burst power on demand. The thermal coupling ensures immediate response to the power demand; the electrical coupling provide: a means for regeneration. The system can be run in the reverse or electrolysis mode after the burst power operation, to produce the basic reactants $\mathrm{H}_{2}$ and $\mathrm{O}_{2}$ from the reaction product, $\mathrm{H}_{2} \mathrm{O}$. The system can be recharged and ready for the next burst operation in a time that is govemed by the power level of the reactor power system. The system has been analyzed in some detail and the state points at the various locations under all operating conditions have been determined. In addition, transient analyses have confirmed the ability of the fuel cell system to respond promptly to burst power demands. Overall, the primary incremental technology development need for this system centers around the development of the fuel cell. The focus of the paper will be on the developmental status of the monolithic solid-oxide fuel-cell technology.

\section{Acknowledgments}

The monolithic solid oxide tuel cell is being developed by a team consisting of Argonne National Laboratory, Allied-Signal Aerospace/AiResearch, and ABB Combustion Engineering. This work was sponsored by the Defense Advanced Research Projects Agency of the U.S. Department of Defense under ARPA Order No. 4850. Currently the work is sponsored by the U.S. Department of Energy and Administrated by the Morgantown Energy Technology Center. Argonne National Laboratory is operated for the U.S. Department of Energy under contract No. W-31-109-ENG-38. 
-END-

DATE FILMED

$2 / 27 /$ 
$\mid$ 